\title{
SUPPRESSIVE EFFECTS OF INDOXOLE IN CRYSTAL-INDUCED SYNOVITIS IN MAN*
}

\author{
BY \\ A. DEAN STEELE $\dagger$ AND DANIEL J. MCCARTY, JR. + \\ From the Rheumatology Section, Department of Medicine, Hahnemann Medical College and Hospital, \\ Philadelphia, $\mathbf{P a}$.
}

Faires and McCarty (1962) have described an acute, reversible, non-specific, dose-related inflammatory response in canine and human joints induced by intra-articular injection of sodium urate crystals. Seegmiller, Howell, and Malawista (1962) noted a similar response induced by urate crystal injection into the knees of gouty patients. Steele and McCarty (1966) recently described an experimental model of inflammation in human volunteers using $20 \mathrm{mg}$. urate crystals as a standard phlogistic stimulus and careful measurement of the inflammatory response. Successful suppression of the response by pre-treatment with aspirin, phenylbutazone, colchicine, and methylprednisolone was described. The effectiveness of similar pre-treatment with a new compound, indoxole**, is described herein.

The structural formula of indoxole, 2, 3 bis (p-methoxyphenyl)-indole, is shown in Fig. 1.

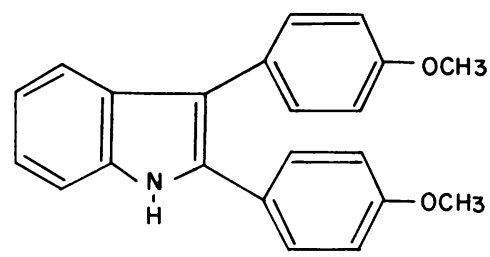

2,3 bis ( $p$ - methoxyphenyl) - indole

Fig. 1.-Chemical formula of indoxole.

Standard screening studies in animals had shown that this compound possessed anti-inflammatory, antipyretic, and analgesic activity. It is rapidly absorbed after oral administration in Lipomul Oral

*Supported in part by grant No. T1 AM 5201-05, USPHS, Bethesda, Md., and by a grant-in-aid from the Upjohn Company, Kalamazoo, Michigan.

tInstructor in Medicine and Co-ordinator, Hahnemann Medical Service, Philadelphia General Hospital.

$\ddagger$ Associate Professor of Medicine and Head, Section of Rheumatology; Markle Scholar in Academic Medicine.

**Indoxole supplied by the Upjohn Co., Kalamazoo, Michigan. or Tween 80 and blood levels persist for several hours. Preliminary data obtained in human studies suggested that a dose of up to $2.4 \mathrm{~g}$./day could be safely tolerated. $\nmid \dagger$

\section{Material and Methods}

All subjects were normal healthy adult men under 40 years of age with no previous history of joint disease, no abnormality of the knees on $x$-ray or physical examination, and a normal serum urate level $(<5.5 \mathrm{mg}$. per cent.).

Monosodium urate monohydrate microcrystals were prepared by methods previously described (McCarty and Faires, 1963); $20 \mathrm{mg}$. urate crystals were suspended in $1 \mathrm{ml}$. isotonic saline and kept in sterile vials. $+\ddagger$

After surgical preparation of the skin with tincture of merthiolate and 70 per cent. alcohol, a superficial incision was made and a polyethylene catheter was inserted into the knee joint through a 17-gauge needle and left in place during the experiment. Details of joint catheterization are described elsewhere (Steele and McCarty, 1966). $20 \mathrm{mg}$. urate crystals $+\ddagger$ were injected into the knee joint followed by $1 \mathrm{ml}$. isotonic saline used to rinse the vial containing the crystals.

Serum and joint fluid levels of indoxole were determined on an ethyl acetate extraction of alkaline samples and subsequent fluorimetric analysis of an ethanolic solution of the extract residue. ${ }^{\dagger} \uparrow$

\section{Inflammatory Index}

(1) Knee Joint Tenderness. - Ink marks were placed just outside the medial and lateral borders of the patella superiorly and inferiorly. Pressure was applied at each mark with a dolorimeter for quantitative measurement of tenderness. This instrument and its use have been described in detail (McCarty, Gatter, and Phelps, 1965). Tenderness units ranged from 0 (no tenderness) to a maximum of 10. Duplicate measurements were made at all four marks on the knee, making possible a maximum tenderness score of 80 units in any subject.

(2) Knee Joint Swelling.--A ${ }^{3 \prime \prime}$ cloth ribbon (grosgrain) was taped to the posterior half of the knee joint with the free ends crossing above the superior patellar

†+Gerard, E. S.: Personal communication.

$\ddagger \ddagger$ Prepared by the Upjohn Laboratories, Kalamazoo, Michigan. 
border. Weights of approximately $15 \mathrm{mg}$. attached to the ends of the ribbon provided standard tension for each measurement. Measurement of the distance between control marks on the ribbon enabled small increments in circumference to be measured.

(3) Knee Skin Temperature.-This was measured with a Cambridge skin temperature meter. Lead wires were taped in place just behind the mid-lateral patellar border.

(4) Volume of Joint Fluid.- The amount aspirated at the termination of the experiment was measured.

The average change in each of these four measurements in fifteen subjects receiving a placebo was valued as 100 . Maximum changes in each parameter in each trial were expressed as a percentage of the average placebo change. The sum of the four percentages for each subject was recorded as an inflammatory index. The oral temperature was recorded each hour during the experimental period.

\section{Synovial Fluid Studies}

Synovial fluid leucocyte counts were performed at intervals in a standard counting chamber; 0.3 per cent. saline was used as a diluent. The average of duplicate counts was recorded. Differential leucocyte counts were performed on smears of undiluted fluid. All joint fluids contained intra- and extra-leucocytic urate crystals at the conclusion of the experiment.

Indoxole Trials.--Eight subjects received $800 \mathrm{mg}$. indoxole by mouth 9 and 2 hours before and 4 hours after the injection of urate crystals up to a total dose of $2,400 \mathrm{mg}$. Blood levels of indoxole were determined at the time of crystal injection and at the end of the trial. Joint fluid levels of the drug were determined on the final aspirate in five of eight subjects. Anti-inflammatory drug effects were evaluated in double-blind trials, each subject serving as his own control. Opposite knees were injected with urate crystals during indoxole and placebo trials.

\section{Results}

The inflammatory response in the fifteen subjects receiving a placebo was manifested initially by an increase in the skin temperature of the injected knee. Swelling, tenderness, and subjective discomfort usually followed in that order. Maximum changes were seen 8 to 10 hours after urate crystal injection. Mild stiffness or minimal aching was noted by two subjects 18 hours after the experiments were terminated; minimal residual knee joint effusion was present in a few subjects at this time.

Changes in the four parameters in the fifteen subjects receiving the placebo varied widely. The following average values served as the basis for calculation of the inflammatory index: knee joint tenderness, 55 units; increase in knee skin temperature, $5 \cdot 0^{\circ} \mathrm{C}$; increase in joint circumference, $8 \cdot 5$ mm.; volume of joint fluid aspirated at conclusion of the experiment, $19.4 \mathrm{ml}$. (Steele and McCarty, 1966).

\section{Effect of Indoxole}

(1) Inflammatory Index (II).-The average II in seven subjects receiving Indoxole was 217 , while the average II in this same group receiving placebo was 328. Indices for the seven paired trials are shown in Fig. 2.

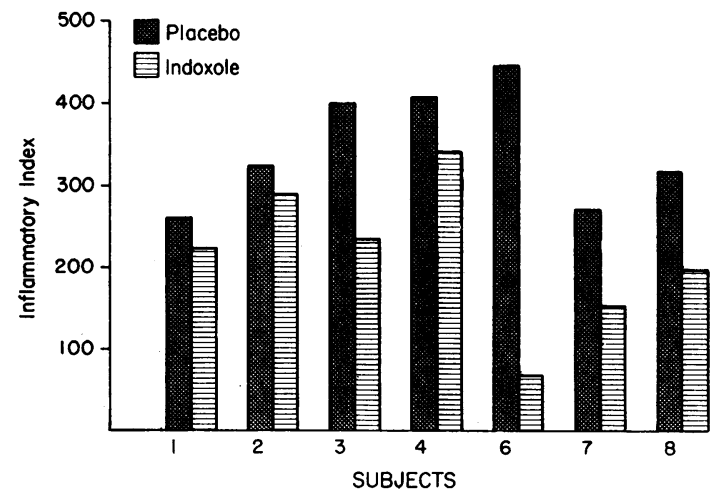

Fig. 2.- Inflammatory indices in seven subjects during indoxole and placebo trials.

The II could not be calculated for Subject 5 as a broken lead wire invalidated temperature measure ments during the placebo trial. Maximum average placebo values for swelling and final volume of joint fluid aspirated were decreased by 28 and 12 per cent. respectively in eight subjects. The reduction of average maximum knee skin temperature in seven subjects was 29 per cent. The most striking effect of indoxole was a 75 per cent. reduction in the average maximum tenderness score. Maximum changes for each parameter are shown for all trials in Table I (opposite).

(2) Synovial Fluid.-Leucocyte counts ranged from 12,800 to 43,100 cells $/ \mathrm{mm}^{3}{ }^{3} 10$ hours after crystal injection. Four subjects showed higher counts when they received indoxole, and four showed higher counts during placebo trials (Table II, opposite). Differential counts all showed a very high percentage of polymorphonuclear cells.

(3) Joint Fluid.-Five subjects showed significant concentrations of indoxole in the final aspirate; the average concentration was $1.65 \mu \mathrm{g}$. $/ \mathrm{ml}$. (range 1.53 to $1 \cdot 87$ ) (Table III, opposite).

(4) Body Temperature.-The average maximum rise in body temperature (oral) in subjects receiving the placebo was reduced by 52 per cent. by indoxole. Maximum temperature changes are shown in Table IV (opposite). 
TABLE 1

MAXIMUM CHANGES IN INDICES OF INFLAMMATION IN EIGHT PLACEBO AND INDOXOLE TRIALS AFTER INTRA-ARTICULAR INJECTION OF SODIUM URATE CRYSTALS

\begin{tabular}{|c|c|c|c|c|c|c|c|c|}
\hline \multirow[t]{2}{*}{$\begin{array}{c}\text { Subject } \\
\text { No. }\end{array}$} & \multicolumn{2}{|c|}{$\begin{array}{c}\text { Knee Joint } \\
\text { Tenderness } \\
\text { (tenderness units) }\end{array}$} & \multicolumn{2}{|c|}{$\begin{array}{c}\text { Knee Joint } \\
\text { Swelling } \\
(\mathrm{mm} .)\end{array}$} & \multicolumn{2}{|c|}{$\begin{array}{c}\text { Injected } \\
\text { Knee Skin } \\
\left.\text { Temperature ( }{ }^{\circ} \mathrm{C} .\right)\end{array}$} & \multicolumn{2}{|c|}{$\begin{array}{l}\text { Final Volume of } \\
\text { Joint Fluid } \\
\text { Aspirated (ml.) }\end{array}$} \\
\hline & Indoxole & Placebo & Indoxole & Placebo & Indoxole & Placebo & Indoxole & Placebo \\
\hline $\begin{array}{l}1 \\
2 \\
3 \\
4 \\
5 \\
6 \\
7 \\
8\end{array}$ & $\begin{array}{r}27 \\
11 \\
50 \\
0 \\
18 \\
0 \\
0 \\
0\end{array}$ & $\begin{array}{l}16 \\
26 \\
76 \\
66 \\
74 \\
80 \\
40 \\
42\end{array}$ & $\begin{array}{r}2 \cdot 5 \\
3 \cdot 0 \\
2 \cdot 0 \\
10 \cdot 5 \\
5 \cdot 0 \\
1 \cdot 5 \\
2 \cdot 0 \\
4 \cdot 5\end{array}$ & $\begin{array}{r}3 \cdot 0 \\
7 \cdot 5 \\
7 \cdot 5 \\
10 \cdot 5 \\
5 \cdot 5 \\
7.0 \\
1 \cdot 5 \\
6 \cdot 0\end{array}$ & $\begin{array}{l}4 \cdot 5 \\
5 \cdot 7 \\
3 \cdot 4 \\
3 \cdot 8 \\
4 \cdot 9 \\
1 \cdot 5 \\
4 \cdot 0 \\
4 \cdot 1\end{array}$ & $\begin{array}{l}6 \cdot 7 \\
3 \cdot 4 \\
4 \cdot 3 \\
3 \cdot 2 \\
-7 \cdot 0 \\
5 \cdot 7 \\
7 \cdot 9\end{array}$ & $\begin{array}{r}11 \cdot 4 \\
24 \cdot 3 \\
10 \cdot 6 \\
28 \cdot 2 \\
16 \cdot 0 \\
4 \cdot 2 \\
9 \cdot 8 \\
12 \cdot 4\end{array}$ & $\begin{array}{l}12 \cdot 6 \\
24 \cdot 0 \\
18 \cdot 0 \\
22 \cdot 7 \\
17 \cdot 4 \\
16 \cdot 0 \\
13 \cdot 0 \\
28 \cdot 3\end{array}$ \\
\hline
\end{tabular}

TABLE II

SYNOVIAL FLUID LEUCOCYTE COUNTS*

\begin{tabular}{|c|c|c|c|c|c|c|c|c|c|c|c|c|c|c|c|c|c|c|}
\hline \multirow{2}{*}{$\frac{\text { Subject No. }}{\text { Therapy } \ddagger}$} & \multirow{2}{*}{$\cdots$} & \multirow{2}{*}{$\cdots$} & \multicolumn{2}{|c|}{$1+$} & \multicolumn{2}{|c|}{2} & \multicolumn{2}{|c|}{3} & \multicolumn{2}{|c|}{4} & \multicolumn{2}{|c|}{5} & \multicolumn{2}{|c|}{6} & \multicolumn{2}{|c|}{7} & \multicolumn{2}{|c|}{8} \\
\hline & & & $\mathbf{P}$ & I & $\mathbf{P}$ & I & $\mathbf{P}$ & I & $\mathbf{P}$ & I & $\mathbf{P}$ & $I$ & $\mathbf{P}$ & I & $\mathbf{P}$ & I & $\mathbf{P}$ & $I$ \\
\hline Hours & $\begin{array}{c}3 \\
5 \cdot 3 \\
7 \cdot 7 \\
10\end{array}$ & & $\begin{array}{r}2 \cdot 6 \\
20 \cdot 4 \\
15 \cdot 4 \\
32 \cdot 7\end{array}$ & $\begin{array}{r}1 \cdot 2 \\
18 \cdot 3 \\
33 \cdot 0 \\
28 \cdot 0\end{array}$ & $\begin{array}{r}5 \cdot 4 \\
12 \cdot 9 \\
22.6 \\
18 \cdot 6\end{array}$ & $\begin{array}{r}5 \cdot 6 \\
7 \cdot 0 \\
9 \cdot 8 \\
25 \cdot 2\end{array}$ & $\begin{array}{r}5 \cdot 2 \\
9 \cdot 4 \\
10 \cdot 8 \\
15 \cdot 2\end{array}$ & $\begin{array}{r}8 \cdot 9 \\
10 \cdot 2 \\
24 \cdot 4 \\
32 \cdot 2\end{array}$ & $\begin{array}{r}8 \cdot 1 \\
19 \cdot 4 \\
27 \cdot 8 \\
24 \cdot 1\end{array}$ & $\begin{array}{r}7 \cdot 0 \\
8 \cdot 2 \\
11 \cdot 2 \\
12 \cdot 8\end{array}$ & $\begin{array}{r}5 \cdot 5 \\
12 \cdot 8 \\
29 \cdot 7 \\
39 \cdot 8\end{array}$ & $\begin{array}{r}1 \cdot 2 \\
9.9 \\
29.4 \\
32.4\end{array}$ & $\begin{array}{l}\overline{12 \cdot 4} \\
37 \cdot 4 \\
43 \cdot 1\end{array}$ & $\begin{array}{r}2 \cdot 2 \\
13 \cdot 0 \\
21 \cdot 4 \\
36 \cdot 8\end{array}$ & $\begin{array}{r}7 \cdot 6 \\
17 \cdot 5 \\
38 \cdot 8 \\
39 \cdot 2\end{array}$ & $\begin{array}{r}1 \cdot 2 \\
3 \cdot 6 \\
28 \cdot 0 \\
28 \cdot 4\end{array}$ & $\begin{array}{l}0 \cdot 8 \\
3 \cdot 8 \\
7 \cdot 1 \\
6 \cdot 9\end{array}$ & $\begin{array}{r}1 \cdot 0 \\
1 \cdot 8 \\
8 \cdot 8 \\
18 \cdot 2\end{array}$ \\
\hline
\end{tabular}

*Value given as cells $/ \mathrm{mm}^{3} \times 10^{3} . \quad$ †Each subject served as his own control. $\ddagger \mathrm{P}=\mathrm{Placebo}, \mathrm{I}=\mathrm{Indoxole}$.

TABLE III

INDOXOLE CONCENTRATION IN SERUM AND SYNOVIAL FLUID $\left(\mu \mathrm{g} . / \mathrm{ml}^{-1}\right)$

\begin{tabular}{c|c|c|c}
\hline \multirow{2}{*}{$\begin{array}{c}\text { Subject } \\
\text { No. }\end{array}$} & \multicolumn{2}{|c|}{ Serum } & Synovial Fluid \\
\cline { 2 - 4 } \cline { 3 - 4 } & $0 \mathrm{hrs}$ & $10 \mathrm{hrs}$ & $10 \mathrm{hrs}$ \\
\hline 1 & 3.92 & 1.82 & \\
2 & 2.05 & 1.42 & 1.53 \\
3 & 2.52 & 2.18 & 1.62 \\
4 & 3.08 & 2.09 & 1.69 \\
5 & 4.74 & 2.88 & 1.54 \\
6 & 7.18 & 1.98 & 1.87 \\
7 & 3.32 & 1.81 & \\
8 & 3.95 & & \\
\hline
\end{tabular}

\section{Discussion}

The intra-articular injection of microcrystalline sodium urate into human knee joints provides a useful model for the study of inflammation. At the same time it affords an opportunity to test the efficacy of new or established anti-inflammatory drugs. Previous evaluation of anti-inflammatory drugs using this model has shown the inflammatory index (II) to be a useful empirical device in spite of the recognized and valid statistical objection to adding together unlike phenomena (Steele and McCarty, 1966). Use of the II permits a clean separation of indoxole and placebo-treated subjects. However, the ratio of the average placebo II and the average indoxole II is $1 \cdot 5: 1$, which does not suggest that indoxole is a highly effective anti-inflammatory drug in this experimental model
TABLE IV

MAXIMUM RISE IN ORAL TEMPERATURE ( ${ }^{\circ}$ F.)

\begin{tabular}{c|c|c}
\hline \multirow{2}{*}{ Subject No. } & \multicolumn{2}{|c}{ Therapy } \\
\cline { 2 - 3 } & Indoxole & Placebo \\
\hline 1 & 0.4 & 0.5 \\
2 & 0.6 & 1.4 \\
3 & 1.3 & 1.2 \\
4 & 1.0 & 1.4 \\
5 & 0.9 & 2.9 \\
6 & 0.8 & 1.9 \\
7 & 0.6 & 1.2 \\
8 & 0.6 & 1.6 \\
\hline Mean & 0.8 & 1.5 \\
\hline
\end{tabular}

Average maximum differences in each of the four parameters used to measure anti-inflammatory activity were analysed statistically using the Wilcoxin matched pairs signed-rank test. Differences in joint tenderness and joint swelling were significant at the 0.05 level $(0.01 \leq \mathrm{P} \leq 0.05)$. Differences in the final volume of joint fluid aspirated and the injected knee skin temperature were not statistically significant. When one considers knee joint tenderness alone, it must be recognized that differences may represent only an analgesic effect of indoxole.

The maximum joint fluid leucocyte concentration did not correlate well with the II, being higher at 10 hours after crystal injection in half of the subjects when they received indoxole. Inability to measure the varying joint fluid volumes during the experiment did not permit determination of total cell counts, which are probably more significant than cell concentration. 
This human model allows determination of blood levels and simultaneous intercellular fluid levels of a drug at the site of the inflammatory reaction. (The synovial space is a true intercellular space: Hamerman and Barland, 1966). Serum levels of indoxole were in keeping with levels attained in previous absorption studies in normal humans. The average joint fluid indoxole level was 76 per cent. of the average 10-hour serum level in the five subjects in whom both determinations were made. Whether the presence of the drug in the joint is necessary for its anti-inflammatory action is uncertain because the mechanism of action of the drug is not known.

Differences in oral temperatures may represent an antipyretic rather than an anti-inflammatory effect of indoxole.

The side-effects seen with the administration of phenylbutazone and adrenocorticosteroids are apparently lacking with indoxole.* Only one subject experienced apparent untoward side-effects; nausea occurred during the experimental period followed by vomiting after the experiment was concluded.

Clinical studies evaluating the anti-inflammatory efficacy of indoxole have not been performed.

\section{Summary}

Intra-articular injection of microcrystalline sodium urate into normal human knees provides a useful experimental model of inflammation. This system was used to test the anti-inflammatory effect of a new drug, indoxole, versus a placebo in doubleblind self-controlled trials. Separation of drug and placebo results was possible in each trial on the basis of an inflammatory index derived from objective measurements of knee joint swelling, tenderness, skin temperature, and the volume of fluid aspirated from the joint at the end of the experiment. Differences in average values between indoxole and placebo results were statistically significant for joint swelling and tenderness. The experimental system permitted simultaneous determination of serum and joint fluid indoxole levels.

Indoxole does not appear to be a highly effective anti-inflammatory drug in this experimental model.

The authors are indebted to Earl S. Gerard, M.D., of the Upjohn Company, Kalamazoo, Michigan, for the supply of urate crystals and indoxole used in this study.

\section{REFERENCES}

Faires, J. S., and McCarty, D. J., Jr. (1962). Lancet, 2, 682 (Acute arthritis in man and dog after intrasynovial injection of sodium urate crystals).

Hamerman, D., and Barland, P. (1966). Bull. rheum. Dis., 16, 396 (Structure and function of the synovial membrane).

* Gerard, E. S.: Personal communication.
McCarty, D. J., Jr., and Faires, J. S. (1963). Curr. ther. Res., 5, 284 (A comparison of the duration of local anti-inflammatory effect of several adrenocorticosteroid esters-a bioassay technique).

-, Gatter, R. A., and Phelps, P. (1965). Arthr. and Rheum., 8, 551 (A dolorimeter for quantification of articular tenderness).

Seegmiller, J. E., Howell, R. R., and Malawista, S. E. (1962). J. Amer. med. Ass., 180, 469 (Inflammatory reaction to sodium urate; its possible relationship to genesis of acute gouty arthritis).

Steele, A. D., and McCarty, D. J., Jr. (1966). Arthr. and Rheum., 9, 430 (An experimental model of acute inflammation in man).

Les effets de suppression de l'Indoxole dans la synovite induite par injection crystalline chez l'homme

RÉSUMÉ

L'injection intra-articulaire de micro-crystaux d'urate de sodium dans des genoux humains normaux fournit un type d'inflammation qui constitue un nıatériel expérimental très utile. Cet artifice fut utilisé pour apprécier l'action anti-inflammatoire d'un nouveau produit, l'Indoxole, comparée à celle d'un placébo au cours d'un essai thérapeutique double blind où chaque sujet constitua son propre témoin. La distinction entre les résultats obtenus avec le médicament et le placébo fut réalisée lors de chaque essai en se basant sur un index d'inflammation calculé à partir de mensurations de la tuméfaction du genou, de sa sensibilité, de la température cutanée et du volume du liquide retiré par aspiration de l'articulation à la fin de l'expérience. Les différences entre les moyennes des valeurs obtenues avec Indoxole et placébo furento statistiquement significatives en ce qui concerne la tuméfaction et la sensibilité de l'articulation. Le procédé expérimental permit une détermination simultanée des taux d'Indoxole dans le sérum et dans le liquide articulaire.

L'Indoxole ne semble pas être un médicament doué d'un pouvoir anti-inflammatoire élevé si l'on en juge d'après les résultats de ces expériences.

Los efectos anti-inflamatorios de Indoxole en la sinovitis inducida en el hombre por inyección cristalina

\section{SUMARIO}

La inyección intra-articular de micro-cristales de urato de sodio en rodillas humanas normales produce un tipo de inflamación que se presta bien al estudio experimental. Este procedimiento fué empleado para determinar la acción inflamatoria de un nuevo producto, Indoxole, que fué comparado a un placebo en un ensayo terapéutico double-blind, en el cual cada sujeto constituía su propio control. La distinción entre los resultados obtenidos con el producto y los con el placebo se hizo con la ayuda de un índice de inflamación derivado de mediciones de la hinchazón de la rodilla, de su sensibilidad, de la temperatura cutánea y del líquido aspirado de la articulación al final del experimento. Las diferencias entre los promedios de los valores obtenidos con Indoxole y con el placebo fueron estadísticamente significativas respecto a la hinchazón y la sensibilidad de la articulación. Este procedimiento experimental permitió una determinación simultánea de las cifras de Indoxole en el suero y en el líquido articular.

A juzgar por los resultados obtenidos en esta investigación, el Indoxole no parece tener mucho poder antiinflamatorio. 